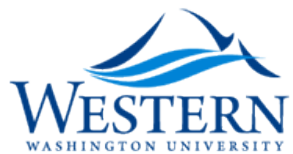

Western Washington University

Western CEDAR

$5-1998$

\title{
Environmental History: Profile of a Developing Field
}

Mart A. Stewart

Western Washington University, mart.stewart@wwu.edu

Follow this and additional works at: https:// cedar.wwu.edu/history_facpubs

Part of the United States History Commons

\section{Recommended Citation}

Stewart, Mart A., "Environmental History: Profile of a Developing Field" (1998). History Faculty and Staff Publications. 51. https://cedar.wwu.edu/history_facpubs/51

This Article is brought to you for free and open access by the History at Western CEDAR. It has been accepted for inclusion in History Faculty and Staff Publications by an authorized administrator of Western CEDAR. For more information, please contact westerncedar@wwu.edu. 


\title{
Society for History Education
}

\author{
Environmental History: Profile of a Developing Field \\ Author(s): Mart A. Stewart \\ Source: The History Teacher, Vol. 31, No. 3 (May, 1998), pp. 351-368 \\ Published by: Society for History Education \\ Stable URL: http://www.jstor.org/stable/494883 \\ Accessed: 08/12/2014 17:57
}

Your use of the JSTOR archive indicates your acceptance of the Terms \& Conditions of Use, available at http://www.jstor.org/page/info/about/policies/terms.jsp

JSTOR is a not-for-profit service that helps scholars, researchers, and students discover, use, and build upon a wide range of content in a trusted digital archive. We use information technology and tools to increase productivity and facilitate new forms of scholarship. For more information about JSTOR, please contact support@ jstor.org. 


\title{
Environmental History: Profile of a Developing Field
}

\author{
Mart A. Stewart \\ Western Washington University
}

IN THE LAST TWENTY-FIVE YEARS, and especially in the last ten years, environmental history in the United States has become a recognized field with a strong core of both individual and institutional support. An increasing number of historians are specializing in it. Graduate students can now study with prominent environmental historians in Ph.D. programs at several institutions and can earn a doctorate in the field. The number of academic conferences focused on environmental studies and history have proliferated in the 1990s. Environmental historians have also had their own organization, the American Society for Environmental History, and journal, the Environmental History Review (recently merged with Forest and Conservation History into a new journal, Environmental History, with a combined subscription list of about 2,000), since the mid1970s. Attendance at the biennial ASEH meeting continues to grow. Many history departments in American universities now also offer introductory-level courses in the field. History departments in the West, where the field has deeper roots, have long had courses on the books in environmental history, but universities in other regions are now also offering courses. Many also have environmental studies programs or even separate institutes or colleges that include environmental history as part of their curriculum. Some departments and programs are also now offering advanced courses that often cross disciplinary, as well as na- 
tional boundaries: courses in comparative or world environmental history, or in the history of the relationship between science, technology, and the environment, for example. Increasingly, K-12 teachers are integrating environmental history into traditional curriculums or are developing separate course components or, in some cases, separate courses, in the field. ${ }^{1}$

Broadly conceived, environmental history is the history of the role and place of nature in human life, the history of all the interactions that societies have had with the nonhuman past, in their environs. Within this broad definition, many species of environmental history have evolved. Previous to the $1980 \mathrm{~s}$, historians who focused on the interactions of human and nature, like Samuel Hays in the small classic, Conservation and the Gospel of Efficiency, and Roderick Nash in the enormously influential Wilderness and the American Mind, tended to do a variety of traditional political history and intellectual history that concentrated on the development of conservation and environmental politics. Hays studied and explained the origins of the conservation movement in the Progressive reform movement in late nineteenth-century America; Nash tracked three hundred years of American ideas about wilderness and explained the consummation of those ideas in "wilderness politics" and in the wilderness preservation movements of the twentieth century. ${ }^{2}$ Biographers who have written about the lives of Frederick Law Olmstead (as landscape designer and parkmaker), the nature-loving transcendentalist Henry David Thoreau, the wilderness seer John Muir, or the ecologist and "land ethic" progenitor Aldo Leopold, have added a strong environmental dimension to traditional biography and the history of ideas, and these studies can also be included under the rubric of environmental history. Geographers, especially historical geographers, have also contributed significantly to the development of environmental history as a field. ${ }^{3}$

Previous to the redefinition of the field in the 1980s, historians of science and historians of ideas who wrote about the development of ideas of nature in science also produced a variety of environmental history. The most influential of these have been Clarence Glacken's Traces on the Rhodian Shore: Nature and Culture in Western Thought from Ancient Times to the End of the Eighteenth Century; and Keith Thomas' Man and the Natural World: A History of the Modern Sensibility, 1500-1800. ${ }^{4}$ Some medical historians were also attentive to the interactions of nature and society in their explanation of human perceptions of, and reactions to, significant disease pathogens: for example, Charles Rosenberg's The Cholera Years: The United States in 1832, 1849, 1866, about the different reactions of Americans to successive cholera epidemics in the mid- 
nineteenth century; and Alfred Crosby's Epidemic and Peace, 1918 (recently published again as America's Forgotten Pandemic: The Influenza of 1918), about the Spanish influenza epidemic of 1918-19, which claimed 25 million lives, more than were killed by the fighting in World War I. Also, in a keystone essay published in 1976 in the William and Mary Quarterly, "Virgin Soil Epidemics as a Factor in the Aboriginal Depopulation of America," Crosby wrote better than anyone about the exotic microorganisms introduced by the first Europeans in North America that killed huge numbers of native Americans. ${ }^{5}$

Since the early 1980s, and especially since the publication of Donald Worster's Dust Bowl: The Southern Plains in the 1930s (1979) and William Cronon's Changes in the Land: Indians, Colonists and the Ecology of New England (1983), environmental history has become a more complicated field. ${ }^{6}$ It has also expanded enormously and has become marked by considerable debate among its practitioners about the goals and purposes of environmental history, as well as over differences of interpretation of key issues. Environmental historians have begun to argue with each other, and argue with each other a great deal, a development that more than any other indicates that the field has acquired disciplinary maturity and has come into its own in American academic life.

The mosaic of recent developments in environmental history can be arranged according to the following taxonomy, into three crude categories. $^{7}$ The discovery of the physical attributes of past environments, the changing distribution of plants and animals, of landforms and climate, and the study of changes in past environments makes up one variety of environmental history. This category concentrates on the environment itself, and has been done best by scientists who take change over time seriously or who are also historians. They study, for example, tree rings or ice cores to determine climate change and pollen analysis that explains past floral distribution and change. When this "historical ecology" is connected to changes in human culture, it has become environmental history. A good example of this kind of history comes not from American historians, but from France and the Annales School, Emmanuel Le Roy Ladurie's Times of Feast, Times of Famine: A History of Climate Since the Year 1000. Studies of change in past environments are often essential to the doing of environmental history. William Cronon depends on pollen studies to explain changes in forest cover in post-contact colonial New England in Changes in the Land; and Donald Worster depends on information about drought cycles on the Great Plains to help him explain the great drought of the early 1930s in Dust Bowl. Dan Flores puts to good use similar information from pollen analysis and dendroclimatic histories 
to help him recreate a history of fluctuations in buffalo populations in his discussion of the relationship between these fluctuations and Native American hunting practices on the Great Plains in "Bison Ecology and Bison Diplomacy: The Southern Plains from 1800 to 1850," in which he argues that bison populations were destined to decline precipitously, partly because of Native American hunting, even if whites had not intervened. In another example, Stephen Pyne uses information about long-term fire cycles to strengthen his analysis of "fire cultures" in various parts of the world in World Fire: The Culture of Fire on Earth. ${ }^{8}$

The second category of environmental history, which is more the province of historians, focuses on the various ways people have tried to transform nature into a system that works for them, that provides sources or produces sources for their subsistence and consumption. This kind looks at how livelihoods are entangled in nature, how economic, social, political, and ecological relationships are woven together, and what this has meant, in terms of environmental change. Examples of this kind of history are Donald Worster's Rivers of Empire: Water, Aridity, and the Growth of the American West; John Opie's Ogallala: Water for a Dry Land; or studies by Jack Kirby of the James River-Ablemarle Sound region below the Chesapeake or my own on the Georgia lowcountry. ${ }^{9}$ Cronon's Changes in the Land also fits into this category. These studies have looked not just at the environment, but how modes of production have been developed by different groups of humans, how these have changed the environment or have had an essential connection to the local environment, but also how different groups of humans have gained or lost power as modes of production have changed. This kind of history takes the physical environment seriously-and is a kind of historical materialism - that assumes that encounters with the material world are defining encounters for human society.

The third category of environmental history takes as its subject the more intangible, ideological, or mental, or perceptual, or cultural encounters with nature: myths, iconographic representations, particular institutions, bodies of laws, and the likes, that have been an important component or expression of a group's interaction with nature. The study of ideas of nature belong to this group, though many of the more recent studies have seen idea-formation and cultural construction as a much more complex - and much more powerful-process than earlier historians of environmental ideas assumed. Some studies that have analyzed the cultural history of nature in the postmodern era, for example, have deconstructed the Walt Disney version of the Bambi story as representative of the American vision of nature since World War II; others have analyzed the version of nature that is presented by The Nature Company 
and other nature-marketing ventures that have bloomed in the last twenty years, or studied images of nature in popular television nature shows and how these have shaped or reflect public perceptions of nature. A recent bloom of literature on theme parks and nature, especially on the packaging and commodification of nature in nature theme parks and in enterprises for ecotourists, also looks at the "culture of nature." The best synthesis of studies of this sort is Alexander Wilson's The Culture of Nature: North American Landscapes from Disney to the Exxon Valdez. ${ }^{10}$

Other historians have looked more critically at maps and seen them not as transparent versions of nature but as highly calculated representations of the environment, just as important for what they leave out and conceal as for what they reveal. Historians such as Greg Nobles-borrowing from J. Brian Harley, the geographer who has been most prominent in this direction of inquiry - have parsed out the fictional content of maps and have identified the hidden assumptions about space and about nature that are contained within them. Others have looked at how we name significant landforms and what this naming process means. A good work of this sort is Paul Carter's The Road to Botany Bay: An Exploration of Landscape and History, in which the author explains that the process of attaching new names to landforms and to significant-and useful, in European terms - points on a landscape was a significant stage in the process of colonization. Carter argues that when European explorers named - or more properly, renamed - the lands they "discovered," they completed the first stage of domination. These and other works have analyzed how mental or cultural constructions of nature both express and reinforce the relationship of a group or society to nature. ${ }^{11}$

However useful the above categories are for measuring the field, they do not define it. Most practicing environmental historians-like all historians-define their field of inquiry in dialogue with other historians, but also in dialogue with the data that is available to them and with the subjects they are studying. Some of the best work has integrated, or even ignored, the above categories. Arthur McEvoy's The Fisherman's Problem: Ecology and Law in the California Fisheries, 1850-1980 is a good example of a study that combines a discussion of environmental change (in the California fisheries), changes in modes of production (industrialization of the fisheries), and an ideology of nature, as embodied in a changing body of law defining and regulating the fisheries. Theodore Steinberg's Nature Incorporated: Industrialization and the Waters of New England, a study of textile industrialization, changes in the law, and environmental change on New England rivers in the early nineteenth century is another example of a work that reflects all three types of environmental history. Several major studies defy categorization: Tho- 
mas Dunlap's Saving America's Wildlife: Ecology and the American Mind, 1850-1990, tracks the interaction of over a century of changes in American attitudes about wildlife, wildlife science, and policy formation, application, and change; William McNeill's Plagues and Peoples explains the social and cultural effects of epidemic diseases; and Alfred Crosby's Ecological Imperialism: The Biological Expansion of Europe, 900-1900, is a grand, Pangaian view of the biological change that was a consequence of the discovery, exploration, and colonization of various parts of the globe by Europeans. ${ }^{12}$

Since the mid-1990s the field has continued to develop in often imaginative directions. Several issues and themes have taken center stage:

1) What is nature? As Raymond Williams pointed out some time ago, "nature" is the "most complex word" in the English language ("culture," he explains, is nearly as complex in meaning). ${ }^{13}$ Environmental historians are finding Williams' observation to be accurate to the point that it threatens to undermine the practice of environmental history itself. In the past, environmental historians had some confidence that they could go to scientists, especially to ecologists, to find a usable model of nature that they could then integrate into their scholarly work. ${ }^{14}$ Ecology also has not escaped history (and increasing complexity), however, and no longer gives the sure answers that environmental historians could depend upon a mere fifteen years ago.

In the 1970s, a new generation of ecologists discovered much more disorder, disequilibrium, and "disturbance" in nature than ecologists had previously imagined. They began to argue that nature is not the relatively stable complex of either organisms or processes that ecologists had earlier in the century said it was. Nature, some have argued, is little more than a fluctuating array of populations of individuals with no inherent ties that bind. The central certainty, these ecologists say, is that things change, and change erratically and unpredictably. ${ }^{15}$

Donald Worster has written most perceptively about the consequences of this development: he observes that environmental historians no longer have a yardstick against which they can measure change. If nature is nothing but a shimmer of populations in space and time, then any effort to explain "nature" and compare human impact against it-other than the most obvious environmental disasters, the dust bowls, toxic waste deserts, and strip mines-becomes only a guessing game. Although one could argue that Worster exaggerates the decline of ecosystem ecology as a useful guide for environmental historians, he is accurate in his assessment of where the discipline of ecology now stands. The splendid con- 
sensus is gone that existed from the late 1950s through the 1970s, when ecologists could speak confidently for the environmental movementthey can no longer provide the sure model of nature against which historians can measure human impact. Historians need not, however, despair; some ecological studies can still help them explain past environmental processes. Indeed, though environmental historians have become increasingly critical of scientific versions of nature and perhaps science itself, they continue to depend on scientific studies that they find clarify their thinking. Those who claim total rejection are perhaps speaking out of both sides of their mouths. ${ }^{16}$

The search for a usable model of nature has come under criticism from the argument that looking for models of nature apart from culture does not make sense anymore. This has forced historians to rethink their approach to the nature-culture interaction completely. This line of thinking falls into several categories:

a) The culture/nature distinction can be found only in modern Western Europe and America. This argument says that the nature/ culture divide makes sense only when talking about modern industrialized nations and that most of the people in most of the world in most of the past have not made such a distinction. ${ }^{17}$

b) In modern industrialized nations, culture permeates natureand in the recent past, in a physical sense as well. Bill McKibben, in The End of Nature, for example, argues that the notion of nature as independent "will not survive the new global pollution-the carbon dioxide and CFC's (and so on).... By changing the weather, we make every spot on earth manmade and artificial." McKibben's book reflects the thinking of some prominent leaders in the environmental movement, but some find his argument wrong-headed. If ecologists can tell us anything, it is that nature has never been as "out there," separate from us, as we believed it was, that it has always changed, with or without human influence - and that if it really matters that we have influenced nature, then it matters mainly to us. ${ }^{18}$

c) Others go even farther, arguing that nature and culture are not. in the first place, independent of one another. This argument contends that the distinction between nature and culture is not something that disappeared because of the activities of humans, but that it was never there in the first place. Apes, dolphins, house pets, and other animals use language, have social behavior, have an emotional life, sometimes use tools - we are not as separate as we would believe. The distinction between the artificial and the natural thus has been and will continue to be a false one. "Organic" sense perception, for example, is "thoroughly enmeshed with sonography systems, magnetic resonance imaging, artifi- 
cial intelligence-linked graphic manipulation systems, scanning electron microscopes" ... and so on, according to Donna Haraway, who has been most prominent in making this argument. In a series of essays and books in which she develops this argument, she says that the distinction between nature and culture, even in the modern age, is a false one: "[Even] our best machines are made of sunshine ... nothing but signals, electromagnetic waves, a section of spectrum." Whatever the fate of this argument, blurring the distinction between the "organic" and the "mechanical" might be meaningful, as Richard White has demonstrated in his recent study of the history of the flow of "energy" (both organic and machine-made) on the major river of the Pacific West, the Columbia. ${ }^{19}$

d) Other scholars argue that when we talk about nature, our understanding is constrained by the rhetorical constructions we use. Language is not a transparent referent to the real thing, but has implication and content of which we must always be aware. This argument has sometimes verged toward a brand of philosophical idealism, the claim that nature is only discourse. Critics of this argument say that those who uphold it ought to run themselves head first into the proverbial tree and see if it's real or if it's a text. A more balanced version of this argument is not idealist, but quite the contrary states that any version of nature we assemble must be regarded with continuing skepticism because of the limitations of the language we use and because the rest of the world, being real, resists human attempts to project definition upon it. The target here is metaphysics and encompassing social theory that claims to clarify fundamentally the meaning of human nature and "natural" nature, and the relations between them both. ${ }^{20}$

All of these possible distinctions between nature and culture strike the same chord: that scholars cannot now, as they did so easily in the past, assume a clear demarcation between the natural and the artificial.

2) What is "wilderness" and the "wild?" Scholars have recently begun to question traditional definitions of the term "wilderness." Essential to a belief in "wilderness" as unsullied nature has been the belief that "nature" in North America was once pristine: after Europeans and Americans ruined it, islands of wilderness came to be seen as the last preserves of nature undamaged by human manipulation and exploitation. This Edenic myth continues to have remarkable power in the United States. However, research on the pre-Columbian American physical environment has shown evidence of sometimes extensive human manipulation of nature and thereby qualified the belief in "pristine nature" beyond recovery. Environmentalists argue that only in relatively undamaged wilderness areas can we find preserves of biodiversity that retain any of original 
richness. They take issue with environmental historians - in their "windowless, climate-controlled conference rooms," one Earth First! critic says-who focus on "wilderness" as an ideological construct without considering the biological component of wilderness. Altogether, this is a discussion that has profound cultural implications in the United States and that may also affect the status of relatively undisturbed natural areas that have survived because they have been designated as "wilderness."

Environmental historians have studied the strong ideological content of the term "wilderness" and how it has exerted great significance in American history. They have identified "wilderness" largely as a political construct, indeed as one of America's defining national myths. Roderick Nash first began writing about this myth over two decades ago. Environmental historians now argue that as "wilderness" became defined in the late nineteenth and twentieth centuries it was a form of colonialism. "Wilderness" lacking any human occupation, they say, rarely existed. When Americans talked about wilderness, they were talking about a nature from which humans-specifically, Native Americans-had been subtracted, because new populations removed or eliminated them. The romantic haze that colored Nash's discussion of wilderness in Wilderness and the American Mind has now been dispelled by a discussion that connects the development of "wilderness" with an exploitative and dominating American colonialism. ${ }^{21}$

3) Environmental history, social meaning, and social justice. Another constellation of issues that has come to the foreground in the recent discussions of environmental historians can be encapsulated in the riddle: Why have we had no African American foresters? Recently, some environmental historians have noticed that the field has paid scant attention in the past to the connection between race, gender, class, ethnicity, and the history of the environment. They argue that this imbalance of attention should be corrected. They urge historians to look at the history of the environment in urban centers, especially, where environmental change - or definitions of the environment-were often played out in terms of social justice and community values. Some historians (and sociologists) have recently looked at the correlation between ethnicity, race, and access to resources or the spatial location of environmental problems. Others have studied how nature becomes "gendered" in certain ways, and what that has meant in terms, again, of access to resources or the valuing or devaluing of certain parts of nature. Any definition of "nature" and the environment, these historians argue, must be considered in terms of substantial categories of social meaning in American society. ${ }^{22}$ 
4) Green history and green politics. Environmental historians have continued to reflect on the relationship between the history they do and the politics they own up to. How green is green history? How green should it be? Is green good? Environmental history has always been informed by a moral and political agenda that has been connected with the environmental movement; this was especially the case twenty years ago. As Alfred Crosby has quipped, the "guiding principles" of environmental historians have not been "those of the boosters, Adam Smith and Karl Marx, but those of the worriers, Thomas Malthus and George Perkins Marsh."23

This moral and political impulse is still present in the work of environmental historians, but not so prominently. And indeed, many historians who have studied the interaction of nature and culture, who have applied the usual standards of historical inquiry, have come up with conclusions that are not palatable to environmentalists. We have already discussed examples of this - the points that "wilderness" is an ideological concept. Other such arguments are that Native Americans were not the first ecologists; that conservationists were motivated in part by political opportunism; that agriculturists in early America who skimmed the soil with damaging agricultural practices were nonetheless more sensitiveand perceptive-toward and of nature than most late twentieth-century Americans; and that a reverence of nature, of the sort that many late twentieth-century environmentalists advocate, is linked inextricably with a culture and an economy that manipulate and control nature. One important recent book argues that the first ideas on conservation in the eighteenth and nineteenth centuries did not come from German universities or the American conservation movement, but from English, French, and Dutch imperialists and native collaborators in Africa, India, and especially on the island colonies of the Caribbean, who earlier worried about disappearing resources, climate change, and soil erosion, and began talking about, and sometimes practicing, conservation and even preservation policies. Environmental history continues to have a politics, and environmental historians continue, along with Marsh and Malthus, to worry. But historians are examining this politics more closely than they once did, and are finding that the naive greenness that was so powerful twenty years ago concealed as much as it claimed. ${ }^{24}$

5) Regionalism/bioregionalism. Some environmental historians have returned to regionalism as a way to organize their study of the interaction between culture and nature. That regions have always existed in American culture makes this approach attractive, though approaches to the past that have emphasized national forces rather than regional ones 
have tended to dominate American historiography in the last twenty years. Some environmental historians are arguing that we need to understand the intricate and complex relationship between humans and nature on the local level if we are to understand it at all. This means focusing on the region as a unit of study - and especially, they say, on the bioregion. Dan Flores has been prominent in making the argument that "the particularism of distinctive places fashioned by human culture's peculiar and fascinating interpenetration with all the vagaries of topography, climate, and evolving ecology that define landscapes - and the continuing existence of such places despite the homogenizing forces of the modern world - ought to cause environmental historians to realize that one of their most crucial tasks is to write well what might be called bioregional histories." Scholars such as Flores take for granted that attention to the environment is necessary and important if we are to understand the past - and if we are to create a usable past for an environmental future. But for the time being, they say, environmental historians should focus on getting it right about specific places without too much in the way of lofty purpose. ${ }^{25}$

6) Global history, global discussions. At the same time that some historians are calling for a closer attention to regions and local landscapes, environmental historians in the United States have also become more aware of the importance of taking on subjects-or at least, asking questions - that have a global, cross-cultural dimension. The incentives in the historical profession to maintain a narrow focus and to remain deeply specialized are very strong. Cross-cultural history presents scholars with several difficult methodological and theoretical challenges, but also with the challenge of parsing out differences in nuance of meaning and angle of approach between academic cultures. Crossing boundaries, like crossing disciplines, can diminish mastery of any specialty that is not by definition cross-cultural. Attempting it can make a young scholar less competitive because of the manner in which institutions and professional life (and careers) are structured in the United States, and that makes them reluctant to undertake comparative studies. However, though American historians know that some specialization is necessary if they are to do history well, they also increasingly recognize that if they never risk crossing boundaries, they will all end up doing studies that are only local or regional in focus, that do not connect to other studies and have no appeal or meaning outside the locale. For this reason, in some graduate programs, cross-cultural scholarship is strongly encouraged, even required, and some press editors seek studies with such broader significance. $^{26}$ 
Environmental historians in the 1990s therefore feel compelled to head in apparently contradictory directions. On the one hand, they recognize the need to do deep research on the intimate and intricate interactions between humans and nature in specific places. On the other hand, they know that they must increasingly couch this research in terms that make sense across cultural boundaries and that will put them in touch with a larger, transnational community of scholars. Environmental historians must also work these contradictions out in the classroom. From all this has come a growing emphasis on comparative environmental history and on the consequences of larger environmental problems in particular locales.

Whatever the questions and orientation of study, historians who study and teach the history of the role and place of nature in human life are working in a dynamic, rapidly changing field that also continues to be connected to public concerns. The field has grown primarily because it is "useful." These questions and issues press upon environmental historians with urgency not just because they emerge out of, or impinge only upon, strategies of scholarship and careers, but because they are connected to concerns about our relationship to the physical world that sustains us all.

\section{Notes}

1. The American Society for Environmental History web page (h-net2.msu.edu/ aseh/), edited by Dennis Williams at Southern Nazarine University, contains information on selected environmental history programs, as well as course syllabi for selected courses in environmental history taught at American universities. Several other web pages provide resources for teachers in the field: for example, "Resources for Teaching Northwest Environmental History" (www.wsu.edu:8080/ forrest/), and "Environmental History: Explore the Field" (www.cnr.berkeley.edu/departments/espm/env-hist/). All of these and the "Forest History Bibliography" web page(wsrv.clas.virginia.edu/ $\sim \operatorname{djp} 2 n /$ biblios/fhs.html) provide bibliographic resources. The web page for the Association for the Study of Literature and Environment (wsrv.clas.virginia.edu/ djp2n/asle.html) provides bibliographies and related links that are of interest to environmental historians. A U.S. Library of Congress web site, part of their "American Memory" complex, provides a large number of significant documents, including government documents, photographs and paintings, and entire books (for example, William Smythe's The Conquest of Arid America and John Wesley Powell's Report on the Arid Lands) in the history of the American conservation movement: "The Evolution of the Conservation Movement, 1850-1920" (lcweb2.loc.gov/ammem/amrvhtml/conshome.html). Recently, several textbooks in environmental history have been published: Benjamin Kline, First Along the River: A Brief History of the U.S. Environmental Movement (San Francisco: Acada Books, 1997); John Opie, Nature's Nation: An Environmental History of the United 
States (Harcourt Brace College Publishers, 1998); and Hal K. Rothman, The Greening of a Nation? Environmentalism in the United States Since 1945 (Harcourt Brace College Publishers, 1998). For teachers who want a broader text for postwar America that has a strong environmental component, see Otis L. Graham, A Limited Bounty (McGraw-Hill, 1996). Of use to teachers might be a recently-published collection of benchmark essays in environmental history, from the first nineteen volumes of Environmental History Review and its predecessor, Environmental Review: Char Miller and Hal Rothman, eds., Out of the Woods: Essays in Environmental History (Pittsburgh: University of Pittsburgh Press, 1997).

This study is meant to be merely an introductory discussion of recent studies of historical interactions between human and nature, and mainly of developments in American (and some British) environmental history. The field has grown too large for any one essay to do more than provide an introduction. This essay also omits a discussion of much fine work related to environmental history, in fields such as human ecology and social and cultural anthropology. My thanks to Jack Kirby and to the anonymous referee of this journal for reading earlier drafts of this essay.

2. Samuel P. Hays, Conservation and the Gospel of Efficiency: The Progressive Conservation Movement, 1890-1920 (Cambridge: Harvard University Press, 1959); Roderick Nash, Wilderness and the American Mind (New Haven: Yale University Press, 1982 , 3rd ed.). In a later book, Hays considers the political history of post-World War II environmentalism: Beauty, Health, and Permanence: Environmental Politics in the United States, 1955-1985 (New York: Cambridge University Press, 1987).

3. Elizabeth Stevenson, Park Maker: A Life of Frederick Law Olmstead (New York: Macmillan, 1977); Paul Brooks, Speaking for Nature: How Literary Naturalists from Henry Thoreau to Rachel Carson Have Shaped America (San Francisco: Sierra Club Books, 1983); Michael Cohen, The Pathless Way: John Muir and American Wilderness (Madison: University of Wisconsin, 1984); Frederick Turner, Rediscovering America: John Muir in His Time and Ours (New York: Viking, 1985); Susan Flader, Thinking Like a Mountain: Aldo Leopold and the Evolution of an Ecological Attitude Toward Deer, Wolves, and Forests (Columbia: University of Missouri, 1974). Geographers, especially historical geographers, have helped shape environmental history. Carl Sauer, D.W. Meinig, Yi-Fu Tuan, David Lowenthal, and Louis DeVorsey have all made contributions to the development of environmental history as a field.

4. Clarence J. Glacken, Traces on the Rhodian Shore: Nature and Culture in Western Thought from Ancient Times to the End of the Eighteenth Century (Berkeley: University of California Press, 1967); and Keith Thomas, Man and the Natural World: A History of the Modern Sensibility, 1500-1800 (New York: Pantheon Books, 1983; earlier in Great Britain).

5. Charles Rosenberg, The Cholera Years: The United States in 1832, 1849, 1866 (Chicago: University of Chicago Press, 1962); Alfred Crosby, Epidemic and Peace, 1918 (Westport, Conn.: Greenwood Press, 19i $\rightarrow$ Alfred Crosby, "Virgin Soil Epidemics as a Factor in the Aboriginal Depopulation of America," The William and Mary Quarterly 3d ser., 33 (April 1976): 289-99.

6. Donald Worster, Dust Bowl: The Southern Plains in the 1930s (New York: Oxford University Press, 1979); William Cronon, Changes in the Land: Indians, Colonists and the Ecology of New England (New York: Hill and Wang, 1983). Cronon's prizewinning book, Nature's Metropolis: Chicago and the Great West (New York: Norton, 1991) has also been widely influential.

7. This is a revised version of the taxonomy used $\rightarrow$ Donald Worster to explain developments in environmental history in "Transformations of the Earth: Toward an 
Agroecological Perspective in History" Journal of American History 76 (March 1990): 1087-1106. The field has grown so rapidly in the last five years that this taxonomy, even as I have stretched and modified it, barely serves any longer.

8. A good guide to the scientific study of past environments is J. Robert Dodd and Robert J. Stanton, Paleoecology: Concepts and Application (New York, 1981). The Annales School has pioneered, among historians, the application of the study of past environmental change to historical phenomenon. Especially influential in the United States has been the work of Fernand Braudel and Emmanuel Le Roy Ladurie. See Le Roy Ladurie, Times of Feast, Times of Famine: A History of Climate Since the Year 1000 (Garden City, N.Y.: Doubleday, 197 $\rightarrow$ Dan Flores, "Bison Ecology and Bison Diplomacy: The Southern Plains from 1800 to 1850," Journal of American History 78 (September 1991): 465-485; and Stephen Pyne, World Fire: The Culture of Fire on Earth (New York: Holt, 1995).

9. Donald Worster, Rivers of Empire: Water, Aridity, and the Growth of the American West (New York: Pantheon Books, 1985); John Opie, Ogallala: Water for a Dry Land (Lincoln: University of Nebraska Press, 1993); Jack Temple Kirby, Poquosin: A Study of Rural Landscape and Society (Chapel Hill: University of North Carolina Press, 1995); Mart Stewart, 'What Nature Suffers to Groe': Life, Labor, and Landscape on the Georgia Coast, 1680-1920 (Athens: University of Georgia Press, 1996). See also Timothy Silver's work, which does for the colonial Southeast what Changes in the Land does for New England: A New Face on the Countryside: Indians, Colonists, and Slaves in the South Atlantic Forests, 1500-1800 (Cambridge: Cambridge University Press, 1990).

$10 \rightarrow$ Ralph H. Lutts, "The Trouble with Bambi: Walt Disney's Bambi and the American Vision of Nature," Forest and Conservation History 36 (1992): 160-171; Jennifer Price, "Looking for Nature at the Mall: A Field Guide to the Nature Company," and Susan G. Davis, "Touch the Magic," in Uncommon Ground: The Reinvention of Nature, ed. William Cronon (New York: Norton, 1996); Bill McKibben, The Age of Missing Information (New York: Plume, 1993); Charles Siebert, "The Artifice of the Natural: How TV's Nature Shows Make All the World a Stage," Harper's Magazine (February, 1993): 43-51; Michael Sorkin, ed., Variations on a Theme Park: The New American City and the End of Public Space (New York: Hill and Wang, 1992; Anthony Wylson, Theme Parks, Leisure Centers, Zoos, and Aquaria. (New York: J. Wiley \& Sons, 1994); Alexander Wilson, The Culture of Nature: North American Landscapes from Disney to the Exxon Valdez (Cambridge, Mass: Blackwell, 1992).

$11 \rightarrow$ Gregory H. Nobles, "Straight Lines and Stability: Mapping the Political Order of the Anglo-American Frontier," Journal of American History 80 (June 1993): 9-35; J. Brian Harley, The History of Cartography (Chicago: University of Chicago Press, 1987), $c \rightarrow$ "Rereading the Maps of the Columbian Encounter," Annals of the Association of American Geographers 82 (1992): 522-542; Paul Carter, The Road to Botany Bay: An Exploration of Landscape and History (New York: Knopf, 1988).

12. Arthur McEvoy, The Fisherman's Problem: and Law in the California Fisheries, 1850-1980 (New York: Cambridge University Press, 1986); Theodore Steinberg, Nature Incorporated: Industrialization and the Waters of New England (New York: Cambridge, 1991); Thomas R. Dunlap, Saving America's Wildlife: Ecology and the American Mind, 1850-1990 (Princeton: Princeton University Press, 1988); William H. McNeill, Plagues and Peoples (New York: Anchor Books, 1989); and Alfred Crosby, Ecological Imperialism: The Biological Expansion of Europe, 900-1900 (New York: Cambridge University Press, 1986). See also Stephen J. Pyne, Fire in America: A Cultural History of Wildland and Rural Fire (Princeton: Princeton University Press, 1982). 
I have not discussed the large body of scholarship that looks at the history of particular environmental problems and that has a deliberate public policy focus: for example, Nancy Langston, Mountain Dreams, Mountain Nightmares (Seattle: University of Washington Press, 1995), on the history of the relationship between public attitudes, public policy and the degradation of the forests in the Blue Mountains of eastern Oregon. I have also slighted urban environmental history, such as Anne Whiston Spirn, The Granite Garden: Urban Nature and Human Design (New York: Basic Books, 1984); John A. Jakle, Derelict Landscapes: The Wasting of America's Built Environment (Savage, Md.: Rowman and Littlefield, 1992) and Martin Melosi's work on the history of urban waste and waste disposal. See also the section on environmental history and social justice below.

13. Raymond Williams, Keywords: A Vocabulary of Culture and Society (London: Croom Helm, 1976), 76-82, 184-189.

14. See, for example, Cronon, Changes, pp. 10-15.

15. Donald Worster has discussed parts of these developments in ecology in several of the essays in the recent The Wealth of Nature (Oxford University Press, 1993) and in a new section in a new edition of Nature's Economy: A History of Ecological Ideas (Cambridge: Cambridge University Press, 1994, 2nd edition). For the early history of ecology, see also Ronald C. Tobey, Saving the Prairies: The Life Cycle of the Founding School of American Plant Ecology, 1895-1955 (Berkeley: University of California Press, 1981).

16. Though Odum's Fundamentals of Ecology and its complex discussion of ecosystem ecology is no longer the central authority (it was almost biblical in its authority for about twenty years after its first publication in 1953) in the training of ecologists, the concentration of Odum and disciples on energy exchanges, independent of any assertions of "equilibrium," continues to be a vital part of the study of nature by ecologists. And though ecologists are now seeing many more perturbations in nature and much less stability, the assumption by "disturbance" ecologists that there is a "long-range disturbance regime" or even a "chaos" that, paradoxically, can be identified, even if only in terms of populations and the processes they are subjected to, indicates that ecologists have not given up hope of discovering patterns of order in nature. The strong interest among conservation ecologists, landscape ecologists, and agroecologists in learning how to achieve a modicum of "sustainability"- and that approaching this goal is even possible-also presupposes a very high level of order in nature. More recently, leading ecologists have acknowledged that different problems require different kinds of inquiry, and have called for the development of a "pluralistic ecology" that will ravel back together the various strands of the science. Some environmental historians continue to have a strong commitment to scientific models of nature and accord them considerable privilege: See, for example, John Opie, Ogallala: Water for a Dry Land.

For discussions of pluralism and attempts to create a whole that will accommodate the many, see, for examp $\rightarrow$ Eugene P. Odum, "The Emergence of Ecology as a New Integrative Discipline," Science 195 (March 1977): 1289-1293; Alan Berryman, "Equilibrium or Nonequilibrium: Is that the Question?" Bulletin of the Ecological Society of America 68 (September 1987): 500-1 $\rightarrow$ Robert P. McIntosh, "Pluralism in Ecology," Annual Review of Ecological Systems 18 (1987): 321 - $\rightarrow$;.J. McNaugton, "Diversity and Stability," Nature 333 (May 1988): 204-05; Paul Koetsier, Paul Dey, Greg Miadenka, and Jim Check, "Rejecting Equilibrium Theory-A Cautionary Note," Bulletin Ecological Society of America 71 (December 1990): 229-30. For a sensitive and thorough insider's study of the history of the ecosystem concept in ecology, see Frank Golley, A History of the Ecosystem Concept in Ecology: More than the Sum of the Parts (New Haven: Yale University Press, 1993). A history of ecology in the post-World War II period that 
challenges the view that the Odum school prevailed in the 1950s, and that suggests the history of the science of ecology has been much more complex than Donald Worster and other historians have made it out to be, is: Michael G. Barbour, "Ecological Fragmentation in the Fifties," in Cronon, ed., Uncommon Ground.

17. $\rightarrow$ Richard White, "Environmental History, Ecology, and Meaning," Journal of American History 76 (March 1990): 1111-1116. See also the first section of Carolyn Merchant, Ecological Revolutions: Nature, Gender and Science in New England (Chapel Hill: University of North Carolina Press, 1989).

18. Bill McKibben, The End of Nature (New York: Random House, 1989), p. 58.

19. Donna Jeanne Haraway, "A Manifesto for Cyborgs: Science, Technology, and Socialist Feminism in the 1980s," Socialist Review 15 (1985): 70. See also Haraway, Simians, Cyborgs, and Women: The Reinvention of Nature (New York: Routledge, 1991); Primate Visions: Gender, Race, and Nature in the World of Modern Science (New York: Routledge, 1989). White's book is Organic Machine: The Remaking of the Columbia River (New York: Hill \& Wang, 1995).

20. The foregoing owes much to an excellent discussion of reconsiderations of the nature/culture distinction in Jane Bennett and William Caloupka, eds. Language, Politics and the Environment (Minneapolis, 1993); and Michael E. Soule and Gary Lease, ed., Reinventing Nature? Responses to Postmodern Deconstruction (Washington, D.C., 1995). See a $\rightarrow$ Cronon, "A Place for Stories: Nature, History, and Narrative," Journal of American History 78 (March 1992): 1347-76; and the essays in Cronon, ed., Uncommon Ground.

21. See especially William Cronon, "The Trouble with Wilderness; or, Getting Back to the Wrong Nature," in Cronon, ed., Uncommon Ground, pp. 24-37. Mark David Spence is developing, in a series of articles and forthcoming book, a discussion about the relationship between "wilderness," National Parks, and the subtraction of Native Americans: see, for example, "Crown of the Continent, Backbone of the World: The American Wilderness Ideal and Blackfeet Exclusion from Glacier National Park," Environmental History 1 (July 1996): 29-49. The "pristine nature" myth continues to have a vitality that seems to defy criticism: see, for example, Kirkpatrick Sale, The Conquest of Paradise: Christopher Columbus and the Columbian Legacy (New York: Knopf, 1990); and Seeds of Change: A Quincentennial Commemoration (Washington, D.C.: Smithsonian Institution Press, 1991). For a thorough, deeply documented critique of the myth that also explains the extent to which Native Americans manipulated the shaped environment in the pre-Columbian Americas, $\rightarrow$ William M. Denevan, "The Pristine Myth: The Landscape of the Americas in 1492," Annals of the Association of American Geographers 82 (1992): 369-385.

At the same time, biocentric environmentalists argue that attacks on wilderness are utterly anthropocentric and selfish, and that "pristine," as the poet Gary Snyder has explained, should "now be understood as virtually pristine" places where the unimpeded flow of evolutionary processes and biodiversity remain. See the critique by "deep ecologist " George Sessions, "Reinventing Nature: The End of Wilderness?: A Response to William Cronon's Uncommon Ground," Wild Duck Review 2 (November 1995): 1314, 21. For an attack on Cronon in "his Uncommon Ground ivory tower" by Earth Firster Dave Foreman, see "Around the Campfire," Wild Earth (Winter 1996/7): 4. A more balanced response, "The Wilderness of History," by Donald Worster, can be found in Wild Earth (Fall 1997): 9-13.

22. The most influential of the recent bloom of work focusing on social justice and urban environmental issues has been the study by Robert Gottlieb, Forcing the Spring: The Transformation of the American Environmental Movement (Washington, D.C.: 
Island Press, 1993) The sociologist Robert Bullard opened up a whole area of inquiry on the relationship between race, class, and access to resources and environmental quality in Dumping in Dixie: Race, Class, and Environmental Quality (San Francisco: Westview Press, 1994). See also Giovanna Di Chiro, "Nature as Community: The Convergence of Environment and Social Justice," in Cronon, ed., Uncommon Ground; $\rightarrow$ Martin Melosi, "Equity, Eco-racism and Environmental History," Environmental History Review 19 (Fall 1995): 1-16. A close study of an urban place that takes seriously the relationship between race, class, and environmental problems, and that provides a model for similar studies, is Andrew Hurley, Environmental Inequalities: Class, Race and Industrial Pollution in Gary, Indiana, 1945-1980 (Chapel Hill: University of North Carolina Press, 1995). For a study of a significant construction of race, ethnicity, and nature in early America, see Pamela Regis, Describing Early America: Bartram, Jefferson, Crevecoeur, and the Rhetoric of Natural History (DeKalb: Northern Illinois Press, 1992). For studies of gender and nature, see Gottlieb, Forcing the Spring, Annette Kolodny, The Land Before Her: Fantasy and Experience of the American Frontiers (Chapel Hill: University of North Carolina Press, 1984); Vera Norwood, Made From This Earth: American Women and Nature (Chapel Hill: University of North Carolina Press, 1993); Merchant, Ecological Revolutions; a $\rightarrow$ Virginia Scharff, "Are Earth Girls Easy? Ecofeminism, Women's History, and Environmental History," Journal of Women's History 7 (Summer 1995): 164-175. For the connection between perceptions of climate, regional distinctiveness, and conceptions of race in the antebellum South, see Mart Stewart "Let Us Begin with the Weather?': Climate, Race, and Cultural Distinctiveness in the American South," Nature and Society in Historical Context, ed. Mikulá Teich and Roy Porter (Cambridge University Press, 1997).

23. $\rightarrow$ Crosby, "The Past and Present of Environmental History," American Historical Review 100 (October 1995): 1189.

24. Calvin Martin, "The Indian and the Ecology Movement," in Keepers of the Game: Indian-Animal Relationships and the Fur Trade (Berkeley: University of California Press, 1978), 157-188. The recent work by the British historian Richard Grove, Green Imperialism: Colonial Expansion, Tropical Island Edens and the Origins of Environmentalism, 1600-1860 (Cambridge, 1995), decisively destroys the conceit of American environmentalists and many environmental historians that conservation ideas, for the most part, originated in America and that they came from liberal reformers.

25. $\rightarrow$ Dan Flores, "Place: An Argument for Bioregional History," Environmental History Review 18 (Winter 1994): 1-18. For a critical review of the concept of "bioregionalism" by a geographer, $: \rightarrow$ Stephen Frenkel, "Old Theories in New Places? Environmental Determinism and Bioregionalism," Professional Geographer 46 (1994): 289-95. Both geographers and American Studies scholars have sometimes profitably focused on "landscape" as an environmental unit where nature and culture converge in significant ways. See John Stilgoe's work the American Studies approach to "landscape": for example, Common Landscapes of America, 1580 to 1845 (New Haven: Yale University Press, 1982) and Alongshore (New Haven: Yale University Press, 1994). For studies of "landscape" by geographers, see the relevant pages and citations in Michael Conzen, Thomas Rumney, and Graeme Wynn, A Scholar's Guide to Geographical Writing on the American and Canadian Past (Chicago: University of Chicago Press, 1993). Historians who have done interdisciplinary studies of landscape change over time include: Richard White, Land Use, Environment, and Social Change: A History of Island County, Washington (Seattle: University of Washington Press, 1980); William DeBuys, Enchantment and Exploitation: The Life and Hard Times of a New Mexico Mountain Range (Albuquerque: University of New Mexico Press, 1985); Stewart, 'What Nature Suffers to Groe'; and Kirby, Poquosin. 
26. The Journal of American History has in the last five years added contributing editors from over fifty countries and has been very active in cultivating the study of American history with an international perspective. An e-mail interactive bulletin board, the ASEH listserv, is host to ongoing discussions about environmental history, many of which reflect a burgeoning interest in global environmental history and in making connections across cultural boundaries. The articles published in recent years in environmental history journals also reflect a developing interest among American environmental historians in global environmental history. 